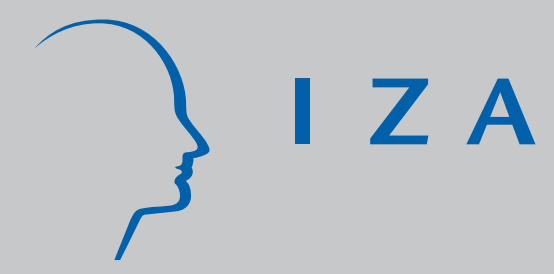

IZADP No. 2871

Optimal Immigration Policy:

Permanent, Guest-Worker, or Mode IV?

Maurice Schiff

J une 2007 


\title{
Optimal Immigration Policy: Permanent, Guest-Worker, or Mode IV?
}

\author{
Maurice Schiff \\ World Bank and IZA
}

\section{Discussion Paper No. 2871 \\ June 2007}

IZA

\author{
P.O. Box 7240 \\ 53072 Bonn \\ Germany
}

Phone: +49-228-3894-0

Fax: +49-228-3894-180

E-mail: iza@iza.org

\begin{abstract}
Any opinions expressed here are those of the author(s) and not those of the institute. Research disseminated by IZA may include views on policy, but the institute itself takes no institutional policy positions.

The Institute for the Study of Labor (IZA) in Bonn is a local and virtual international research center and a place of communication between science, politics and business. IZA is an independent nonprofit company supported by Deutsche Post World Net. The center is associated with the University of Bonn and offers a stimulating research environment through its research networks, research support, and visitors and doctoral programs. IZA engages in (i) original and internationally competitive research in all fields of labor economics, (ii) development of policy concepts, and (iii) dissemination of research results and concepts to the interested public.
\end{abstract}

IZA Discussion Papers often represent preliminary work and are circulated to encourage discussion. Citation of such a paper should account for its provisional character. A revised version may be available directly from the author. 


\section{ABSTRACT \\ Optimal Immigration Policy: Permanent, Guest-Worker, or Mode IV?*}

Host countries have implemented permanent and guest-worker (GW) immigration programs in recent decades, while the temporary movement of service providers under Mode IV of the GATS is one of the issues being negotiated at the Doha Round of the WTO. Though decisions on what programs to adopt have acquired increased urgency, the task has been complicated by host countries' concern with migrants' massive overstaying in past GW programs. This paper contributes to the debate by examining these migration regimes in a model in which the host country maximizes an objective function with respect to i) the size of the migration program, and - in the case of temporary migration - ii) the value of a bond employers must buy and iii) the share of migrants' income whose payment is deferred. The maximization also takes into account the impact of the policy on source country cooperation on illegal immigration, migrants' incentives and their preference for overstaying. The model solves for the policy measures, the overstaying probability, and the level of illegal migration. The paper concludes that the optimal policy is a combination of Mode IV-type and permanent migration.

JEL Classification: F20, F22, J61

Keywords: policy, immigration, permanent, guest-worker, Mode IV, illegal, cooperation

Corresponding author:

Maurice Schiff

Development Research Group

The World Bank

MSN MC3-303

1818 H Street NW

Washington, DC 20433

USA

E-mail: mschiff@worldbank.org

\footnotetext{
* I would like to thank Mohammad Amin, Louise Fox, Vlad Manole, Aaditya Mattoo, Dominique Njinkeu, Cagler Ozden, Martin Ruhs, David Tarr, Pedro Videla, Alan Winters, Dean Yang, and participants at seminars at Central Bank of Chile, Bar-ilan, University of Chile and the World Bank, for their useful comments. The views presented here are those of the author and do not necessarily reflect those of the World Bank, its Executive Directors or the governments they represent.
} 


\section{Introduction}

A number of developed host countries have implemented guest-worker programs in recent decades. A basic feature of these programs is the temporary presence of the foreign guest-workers. The idea underlying these programs is to obtain a permanent increase in the labor force without a permanent increase in the host country's population. ${ }^{1}$ The results have been mixed as a share of the guest-workers failed to return to their home country when their contract period elapsed.

The debate has acquired increased urgency as host country labor shortages have increased in a number of sectors, and host countries are considering alternative temporary migration schemes, ${ }^{2}$ one of which is the temporary cross-border movement of service suppliers under Mode IV. Negotiations on Mode IV have been undertaken in the Doha Development Round of the WTO but with little progress so far, even though migrant overstaying is less likely under Mode IV than under guest-worker programs (Section 4). ${ }^{3}$

The problem of overstaying is the main reason the popularity of guest-worker programs has declined over time. This occurred in the Mexico-US Bracero program and in the Turkey-Germany Gastarbeiter program. The extension of unemployment benefits in the latter program may explain why many laid-off guest-workers remained in Germany after recruitment officially stopped in 1973.

\footnotetext{
${ }^{1}$ Another reason for such a program is to restrict the employment of migrant workers to certain sectors or occupations, which is not possible in the case of permanent migrants.

${ }^{2}$ For instance, an article in the Washington Post of September 5, 2004, refers to labor shortages in the US service industries, stating that "Employers are unable to find enough nurses, engineers, information technology workers, auto mechanics or machinists to fill positions available."

${ }^{3}$ Issues related to Mode IV have been examined, among others, by Walmsley and Winters (2002) and by Winters et al. (2002, 2003) - who find very large gains from Mode IV liberalization - and by various authors in Hoekman, Mattoo and English (2002) and Mattoo and Carzaniga (2003).
} 
Economic migrants living in a host country illegally either enter as illegal immigrants or enter legally as temporary workers or as non-working visa holders (e.g., students or tourists) and overstay. The large number of foreigners living in host countries illegally has led to social and political tensions, with surveys indicating that attitudes toward immigrants have worsened and support for reducing migration has increased. ${ }^{45}$

A number of relatively small-scale guest-worker programs have been initiated in developed host countries in recent years because of greater shortages of skilled labor (nurses, high-tech workers) and unskilled labor in agriculture, construction, domestic services and other. Canada and Mexico have established a program whereby Mexicans who have been screened by their government work in Canadian agriculture for several months and can be rehired if their performance is considered satisfactory. Similar programs have been established between the UK and Baltic countries and between Greece and Albania.

Various proposals are the subject of ongoing debates, including a new guestworker program for Mexican farm labor in the US and a radical reform of Germany's temporary and permanent migration policies, and debates on admitting high-tech workers are taking place in many high-income countries (Ruhs and Chang, 2004). This paper argues that temporary migration programs that are suitably reformed in order to make them more attractive to host countries can play an important role as part of a sustainable migration strategy in the future, particularly - as mentioned above - in the case of Mode

\footnotetext{
${ }^{4}$ Another reason is the decline in demand. Before 1973, immigration was associated with labor shortages and the need for foreign workers. With a decline in growth rates and increased unemployment in the post1973 era, immigration became associated with social problems and a burden on the welfare system.

${ }^{5}$ Regarding the UK, Black (2004) states: "For those who oppose immigration, temporary worker schemes represent a way in which permanent immigration is opened through the back door, since those who arrive temporarily often find ways to stay longer.” Thus, policies that succeed in resolving the temporary workers' overstaying problem should help diffuse one of the main arguments of those opposed to immigration.
} 
IV where migrant overstaying is less likely to take place than under the guest-worker program (see Section 4). This paper examines several reforms designed to achieve this objective.

An important contribution to the analysis of temporary migration of skilled labor is Amin and Mattoo (2005). The authors examine a case where the government's ex ante commitment to a temporary migration scheme is not credible because of a time inconsistency problem. The investment in training a skilled migrant is lost if $\mathrm{s} / \mathrm{he}$ is temporary but not if s/he is permanent. On the other hand, a permanent migrant imposes a greater social cost than a temporary one. Assuming the training cost is greater than the difference in social cost, the optimal ex-post policy once migrants are trained is to allow them to stay. Knowing that, firms invest in training even under a temporary migration policy, resulting in permanent migration ex post. This may help explain the overstaying of skilled labor.

However, host countries are essentially concerned with the overstaying of unskilled migrants because they are much more numerous than skilled migrants, overstaying is more prevalent among them, ${ }^{6}$ and skilled workers impose a smaller social cost than unskilled workers because they tend to integrate more easily into their new social and cultural environment. Consequently, the focus of this paper is on unskilled migrants.

The remainder of the paper is organized as follows. Section 2 provides a description of the guest-worker policy considered in this paper and Section 3 presents the

\footnotetext{
${ }^{6}$ Overstaying is more prevalent among unskilled than among skilled migrants because the latter have a better chance of extending their legal stay or becoming permanent residents, the demand for their skills in the illegal job market is more limited, and they have more to lose if caught.
} 
guest-worker model. Sections 4 and 5 do the same for Mode IV and permanent migration, respectively. Section 6 examines a combination of these policies, while Section 7 looks at circular migration. Section 8 concludes.

\section{Guest-worker Policy}

Two types of policy measures designed to reduce guest-workers' incentive to overstay have been implemented. First, governments or employers in a number of countries defer payment of a share of guest-worker income and pay it with interest at the end of the contract period if the guest-workers leave. Otherwise, guest-workers forfeit the deferred income share. This is done in Taiwan by companies recruiting foreign workers. Similar programs exist in the UK for migrants from the Baltics who work on three-month contracts in the hotel industry and whose salary is deposited in their home country's bank account, and in the US where the same takes place with Jamaican workers. ${ }^{7}$

Second, some countries - including Greece and Israel (see Epstein, Hillman and Weiss, 1999) - implemented a policy where employers must buy a bond which they forfeit if their guest-worker employees overstay. ${ }^{8}$ Singapore has such a program but with many restrictions on who can be admitted, on their behavior and relationships in the country, and with strong penalties for overstaying guest-workers and their employers.

Where penalties are severe and enforcement is serious, such as in Singapore, preventing guest-workers from overstaying is likely to be feasible. However, such

\footnotetext{
${ }^{7}$ It also took place in the early years of the Bracero Program where US employers were required to withhold 10 percent of Mexican workers' earnings, deposit them in a Mexican fund, and pay them upon the workers' return to Mexico.

${ }^{8}$ Some countries (e.g., France) have subsidized the return of immigrants to their home country. This policy has had a negligible impact on migrants' decision to return and is not examined here.
} 
policies are unlikely to be acceptable in liberal democracies. The question is whether illiberal enforcement measures are the only way to resolve the overstaying problem and make guest-worker programs work. This paper claims it is not. It presents a temporary migration (guest-worker and Mode IV) policy package - possibly in combination with permanent migration - that consists of measures that reduce the incentive to overstay and also reduce the number of migrants entering the country illegally.

The host country government incorporates migrants' substitution between guestworker migration and illegal entry in its objective function. The same is true for the degree of source country cooperation in limiting illegal entry into the host country.

Some countries have obliged employers to buy a government bond while others have opted for deferring part of the payment of guest-workers' income. According to Martin (2003, p. 28), no country has made use of both measures. The policy package presented in this paper includes both measures, as well as a third component consisting of establishing some form of cooperation between the host and source countries in the area of controls on the flow of illegal migrants. ${ }^{9}$

The source country has an incentive to cooperate in controlling the flow of illegal migrants entering the host country because of the benefits it obtains from the guestworker program. These include the remittances guest-workers send home, the valuable experience they obtain in the host country, the potential impact in reducing unemployment back home, and the experience of a superior institutional environment which is likely to make guest-workers better citizens when they return. Thus, the implicit

\footnotetext{
${ }^{9}$ Gibney (2000) claims that in the UK, an island with quite effective border controls, the number of overstaying guest-workers is greater than the number of immigrants who came in illegally, though this is unlikely to hold for the US and other countries. The issue of the social cost of immigration in both source and host countries was examined in a model of migration, trade and social capital in Schiff (2002).
} 
threat that the guest-worker program will be curtailed if the source country refuses to cooperate is likely to provide it with a compelling incentive to do so. ${ }^{10}$

Alternatively, host countries might offer to expand the guest-worker program in exchange for cooperation on illegal migration (i.e., cooperation through carrot rather than stick). This seems to have been the case with guest-worker programs developed by Italy and Spain in the 1990s in part to elicit cooperation in reducing illegal immigration from countries like Albania and Morocco, respectively (Martin, 2003). ${ }^{11}$ Given the ineffectual past attempts by major host countries to control illegal immigration, cooperation between source and host countries is likely to be indispensable.

To summarize the guest-worker policy problem, the host country government maximizes its objective function with respect to the guest-worker policy by determining the size of the program, the value of the bond, and the share of the guest-worker's income whose payment is deferred, subject to guest-workers' incentives and preferences, to the degree of migrant substitution between entry as guest-worker and illegal entry, and to source country cooperation on illegal migration.

\section{The Guest-worker Model}

Assume two countries, a developing source country and a developed host country. Individuals live and work for two periods. Both countries are endowed with unskilled labor which produces an identical non-storable good under perfect competition with

\footnotetext{
${ }^{10}$ Pritchett (2004) suggests a number of measures to enhance the development impact of international migration of unskilled labor, including penalties on sending countries and host country employers for guest-workers who overstay.

${ }^{11}$ This view is shared by the International Organization for Migration (IOM, 2004, p. 11) which notes that “... bilateral labour agreements can act as an incentive for labour-sending countries to assume more responsibility to counter irregular migration.”
} 
constant-returns-to-scale technology. The host country benefits from a higher technology

level than the source country, and labor's marginal product - its wage rate - in terms of a tradable non-storable numéraire good is therefore similarly higher (implying identical unit costs in both countries). ${ }^{12}$ Labor in the source country has an incentive to migrate to the host country and earn the higher wage there.

To simplify the analysis, I assume risk-neutrality and $\rho=0$, where $\rho$ is the guestworkers' subjective discount rate. ${ }^{13}$ These assumptions have no qualitative impact on the results. Given the number of developing source country individuals who want to migrate to developed host countries, I assume that the guest-worker quota is filled in both periods. I also assume that the guest-worker quota is small relative to the host country labor force, implying that the wage rate is given exogenously. ${ }^{14}$

Sub-sections 3.1 to 3.3 examine the behavior of guest-workers, employers and the government. Section 3.4 solves for the policy instruments and the size of the guestworker program.

\subsection{Migrants}

Guest-workers' contracts pay a wage rate $W$ for one period. Those who enter the host country at the start of period 1 must decide whether to return to their home country

\footnotetext{
${ }^{12}$ The numéraire good is imported by the source country when migrants send remittances home.

${ }^{13}$ The model does not involve an interest rate since there are no assets, the good is non-storable and individuals have identical preferences.

14 There is an ongoing debate as to whether or not migration reduces native wages. On the one hand, an increase in the supply of foreign labor would tend to lower native wages under the assumption that foreign and native workers are substitutes (Borjas ...). On the other hand, it has been argued that some types of migrants may increase the demand for labor of native substitutes. For instance, an increase in unskilled migrants working as maids may enable skilled native women to enter the labor market, and the latter may result in an increase in the demand for complementary unskilled labor (Kremer and ..., 2004). Moreover, the same is likely to occur because the skilled native women, the newly employed maids and other workers spend (part of) their income.
} 
at the end of that period or overstay and work in the illegal job market in period 2 .

Overstaying guest-workers earn the illegal job market wage rate $W^{I}$ in the second period (unless they are apprehended in which case they earn nothing). Rivera-Batiz (1999) has shown that wages of illegal workers are lower than for similar illegal workers, i.e., $W^{I}<$ $W .{ }^{15}$ Guest-workers returning home at the end of period 1 earn a source country wage rate $W^{S}$ in period 2, with $W^{S}<W^{I}<W^{16}$ At the start of period 2, some source country individuals who were not selected in period 1 enter the host country as guest-workers. None of them overstays since they only have one period left to live.

The overstaying guest-worker's expected income in period 2 is $(1-p) W^{I}$ where $p$ is the probability of being caught, in which case they earn nothing. Given the reality about apprehension of illegal migrants, $p$ is assumed to be equal to zero. ${ }^{17}$ Hence, the overstaying guest-worker's income in period 2 is $W^{I}$.

\footnotetext{
15 The contract's wage rate is assumed to be higher than the wage rate in the illegal job market because employers of illegal workers do not have to comply with minimum wage laws (since illegal workers have no legal protection against such practice), do not have to pay health insurance or social security, and may bear some cost if the worker is apprehended such as replacement costs and/or a penalty for illegal activity. For the US, Rivera-Batiz (1999) finds that male (female) Mexican legal immigrants earn 41.8\% (40.8\%) more than undocumented ones, with more (less) than half the wage gap explained by the difference in status (characteristics). He also finds that undocumented immigrants who were legalized after the 1986 US immigration policy reform showed rapid wage growth in 1986-90, with the gains due mostly to the change in legal status and not to changes in migrant characteristics over time. Note that in their analysis, Epstein et al. (1999) asume $W<W^{I}$.

${ }^{16}$ With $W>W^{I}$, a question is why employers would be interested in hiring legal guest-workers rather than illegal ones. Illegal workers are more likely to be found in smaller businesses, such as restaurants and other small-scale services because they have much to gain and little reputation to lose. On the other hand, large companies or corporations are less likely to employ illegal workers because of the costly loss of reputation or goodwill if found out. Thus, two separable labor markets are assumed, one of large companies that hire legal workers and one of small businesses that hire illegal workers.

17 The share of illegal migrants, including overstaying guest-workers, deported by developed host democracies is negligible, both because a number of industries benefit from their presence and because deporting them in large numbers is unacceptable in a democracy. Former US Homeland Security Undersecretary Hutchinson argued that it is unrealistic to believe that the authorities will reduce the number of illegal immigrants or that the public has the will to uproot them (Washington Times, September 10,
} 
The overstaying cost is the sum of three components: (i) the cost $\alpha W$ of forfeiting the deferred share $\alpha$ of the income $W$ earned; (ii) the income $W^{S}$ the guestworker would have earned upon return to the source country at the end of period 1 ; and (iii) the heterogeneous psychic cost $v_{i}(i=1,2, \ldots, N)$ of living away from home and of living in an illegal status, where $N$ is the number of guest-workers admitted under the policy. Thus, the cost of is $\alpha W+W^{S}+v_{i}$, with $v_{\Psi}$ being the value of $v_{i}$ that equates the overstaying cost and benefit, i.e.:

$v_{\Psi}=W^{I}-\alpha W-W^{S}$.

Assuming the psychic cost $v_{i}$ is distributed uniformly over the unit interval [0, 1], equation (1) implies that a share $v_{\Psi}$ overstays and a share $1-v_{\Psi}$ returns home at the end of period 1.

\subsection{Employers}

Employers' benefit from hiring guest-workers is $W^{N}-W$, where the wage rate $W^{N}$ natives are paid is higher than the wage rate $W$ paid to guest-workers. ${ }^{18}$ Employers must also buy a government bond $B$ which they forfeit if the guest-worker overstays.

2004). Moreover, the number of US employers of illegal immigrants who were fined declined from 1063 in 1992 to 13 in 2002 or by close to 99\% (Time Magazine, September 20, 2004).

${ }^{18}$ What determines $W$ ? Given the large excess-demand, individuals interested in migrating as guestworkers have little or no bargaining power in setting their wage rate in the host country (Kremer and ..., 2004) and would be willing to accept anything above $W^{S}$. I assume that $W^{S}$ is unacceptably low in the developed host country, and the government sets the wage rate at the acceptable minimum $W>W^{S}$. 
Given that the share of overstaying guest-workers is $v_{\Psi}$, the cost to employers is $B N_{1} v_{\Psi} \cdot{ }^{19}$ The total benefit for employers is

$E B=\left(W^{N}-W\right)\left(N_{1}+N_{2}\right)-B N_{1} v_{\Psi}$,

where $N_{1}$ and $N_{2}$ are the guest-workers' quotas in periods 1 and 2, respectively.

In a democracy, guest-workers can join the illegal job market whenever they wish, and there are few if any actions employers can take to reduce the rate of overstaying or eliminate it. Given that reality, it is unclear what this policy's objective is. This is reflected in the solution to the model in Section 3.3.4. A case where employers are assumed to be able to reduce the rate of overstaying is discussed in footnote 23 .

\subsection{Government}

This section examines the policy's social cost and fiscal revenue gains, and specifies the government's objective function. Since the government provides no public services, I assume that fiscal revenues are distributed to the native workers.

\subsubsection{Social Cost}

Immigration results in a social cost $S$ for natives which varies according to the type of migrants involved. Illegal migrants $I M$ consist of illegal entrants $I E$ and overstaying temporary migrants $O M$, i.e., $I M=I E+O M$. Illegal migrants impose a greater social cost on society compared to legal temporary migrants $T M$ (whether guest-

${ }^{19}$ If $\left(W^{N}-W\right)<B v_{\Psi}$, no guest-workers will be hired in period 1. I assume $\left(W^{N}-W\right)>B v_{\Psi}$. 
workers or temporary service providers). Reasons include society's aversion to illegality and to the creation of an underclass, as well as potential negative spillover effects such as a diminished respect for the law and a potential increase in the crime rate. Thus, the social cost $\mu$ generated by temporary migrants is a fraction of that generated by the same number of illegal migrants, with $0<\mu<1$.

The degree of substitution between legal migration and illegal entry depends on the degree of substitution between the two types of migration by potential migrants, and on the degree of source country collaboration on restricting illegal entry into the host country. As discussed in Section 2, the latter increases with the size of the legal migration program. Both of these forces imply a negative relationship between the legal migration programs and the number of illegal entrants, such as $I E_{i}=a-b N_{i}, a>0,0<b<1$.

No guest-workers enter the illegal job market in period 1 since $W^{I}<W$, i.e., $O M$ $=0$. Thus, the number of illegal migrants in period 1 is $I M_{1}=a-b N_{1}$. Note that these illegal migrants remain in the host country in period 2 as well. The number of temporary migrants who overstay in period 2 is $O M_{2}=v_{\Psi} N_{1}$. Hence, the number illegal migrants in period 2 is $I M_{2}=\left(a-b N_{1}\right)+\left(a-b N_{2}\right)+v_{\Psi} N_{1}$ or $I M_{2}=2 a+\left(v_{\Psi}-b\right) N_{1}-b N_{2}$

A plausible assumption is that the social cost of migration increases with the size of the migration program at an increasing rate. I assume that the social cost function is of the form $S_{i}^{I M}=c+d X^{2}$ for illegal migrants and $S_{i}^{T M}=\mu\left(c+d X^{2}\right)$ for legal temporary migrants, where $X$ is the number of migrants.

The social cost $S_{1}$ in period 1 has two components. First, the number of illegal entrants in period 1 is $I E_{1}=a-b N_{1}$. Since there are no overstaying temporary migrants 
in period 1 , the total number of illegal migrants is $I M_{1}=a-b N_{1}$, with social cost $a-b N_{1}^{2}$. Second, the temporary migrants in period 1 have a social cost $\mu N_{1}^{2}$. Thus, the social cost in period 1 is $S_{1}=a+(\mu-b) N_{1}^{2}$. I make the plausible assumption that an increase in the number of guest-workers raises the social cost $S_{1}$, i.e., $\mu>b$.

The social cost $S_{2}$ has four components: the social cost $a-b N_{2}^{2}$ associated with the illegal entrants in period 2, the social cost $a-b N_{1}^{2}$ of the illegal entrants in period 1 (who remain in the host country in period 2), the social cost $v_{\Psi} N_{1}^{2}$ of overstaying guestworkers, and the social cost $\mu N_{1}^{2}$ of guest-workers in period 2. Thus, $S_{2}=2 a+\left(v_{\Psi}-b\right) N_{1}^{2}+(\mu-b) N_{2}^{2}, v_{\Psi}>b$. The total social cost $S C \equiv S_{1}+S_{2}$ is

$$
S C=3 a+\left(\mu+v_{\Psi}-2 b\right) N_{1}^{2}+(\mu-b) N_{2}^{2} \cdot{ }^{20}
$$

\subsubsection{Fiscal Revenue Gain}

Finally, the government benefits from keeping a share $\alpha$ of overstaying guestworkers' income and from keeping the bonds employers forfeit for each overstaying guest-worker. Thus, the government's benefit (fiscal revenue gain) $G B$ is

$$
G B=v_{\Psi} N_{1}(\alpha W+B) \cdot \cdot^{21}
$$

$20 S_{1}=\left[\left(a+(\mu-b) N_{1}\right]^{2}\right.$ and $S_{2}=\left\{2 a+\left(v_{\Psi}-b\right) N_{1}+(\mu-b) N_{2}\right\}^{2} \quad$ is an alternative specification of social cost. However, even after specifying parameter values, the solution for several of the policy variables is some two pages long and the comparative static results are not interpretable.

${ }^{21}$ Another benefit consists of the profits made by the employers of illegal migrants since they typically pay them less than the value of their marginal product. However, these are not considered a benefit in 


\subsubsection{Government Objective Function}

The government maximizes its objective function - which consists of a weighted sum of employers' profits, the natives' social cost of migration, and their benefit from the fiscal revenues they receive. Following Grossman and Helpman (...), I assume that the government gives a greater weight $g$ to employers' profit gains from migration than to the costs and benefits incurred by the native population as a whole, i.e., $g>1$.

Thus, the government's objective function $F_{1}$ is: ${ }^{22}$

$$
\begin{aligned}
& F_{1}=g * E B+G B-S C=g\left[\left(W^{N}-W\right)\left(N_{1}+N_{2}\right)-v_{\Psi} N_{1} B\right]+v_{\Psi} N_{1}(\alpha W+B) \\
& -\left[3 a+\left(v_{\Psi}+\mu-2 b\right) N_{1}^{2}+(\mu-b) N_{2}^{2}\right]
\end{aligned}
$$

\subsection{Solution}

The government maximizes $F_{1}$ with respect to four policy variables, namely the share $\alpha$ of the guest-worker's deferred income, the value $B$ of the bond employers must purchase, and the size of the guest-worker program $N_{1}$ and $N_{2}$. Let us first examine the solution for $B$. Recalling that $g>1$, we have $\partial F_{1} / \partial B=(1-g) v_{\Psi} N_{1}<0$. Thus, the optimal value is:

$B^{*}=0 .^{23}$

democratic host countries because of the illegality of the activities associated with these profits and they are not included in the model.

${ }^{22}$ I have abstracted from any externalities migrants may cause (e.g., congestion) and from any beneficial complementarities between them and natives.

${ }^{23}$ The solution $B^{*}=0$ holds in the case where employers have no influence on guest-workers' behavior. Assume now that they can monitor guest-worker behavior and can reduce $v_{\Psi}=W^{I}-\alpha W-W^{\mathrm{S}}$ to 
The solution for $N_{1}, N_{2}$ and $\alpha$, obtained after much manipulation, is:

$$
\begin{aligned}
& N_{1}^{*}=\frac{1}{3}\left[4(\mu-2 b)+2\left(W^{I}-W^{S}\right)-\sqrt{Z}\right], N_{2}^{*}=\frac{g\left(W^{N}-W\right)}{2(\mu-b)}, \\
& \text { and } \alpha^{*}=\left(\frac{1}{6 W}\right)\left[4(\mu-2 b)+5\left(W^{I}-W^{S}\right)-\sqrt{Z}\right]
\end{aligned}
$$

where $Z=16(\mu-2 b)^{2}+\left(W^{I}-W^{S}\right)^{2}+16(\mu-2 b)\left(W^{I}-W^{S}\right)-12 g\left(W^{N}-W\right)$.

It can be shown that $N_{1}^{*}<N_{2}^{*}$. This is due to the fact that the social cost of overstaying by first-period guest-workers is greater than the benefit from fiscal revenues at the optimum.

\subsection{Comparative Statics}

The results are as expected: $N_{1}^{*}, N_{2}^{*}$ and $\alpha^{*}$ increase with an increase in $g$ (the employers' relative importance), $b$ (the negative impact of the guest-worker program on illegal entry), $W^{N}-W$ (the difference in the wage rate of natives and guest-workers) and with a decrease in $\mu$ (the social cost of guest-workers). Moreover, $N_{1}^{*}\left(N_{2}^{*}\right)\left(\alpha^{*}\right)$ falls (is unchanged) (increases) with $W^{I}-W^{S}$.

$v_{\Psi}^{\prime}=(1-q) W^{I}-\alpha W-W^{S}$ at a cost of $e q^{2}$, where $q$ is the probability of being caught. The optimum level for $q$ is $q^{*}=B N_{1} W^{I} / 2 e$. This scenario was tried but did not provide a tractable solution. 


\section{Mode IV}

A fundamental difference between a guest-worker program and Mode IV is that the former entails a contract for temporary employment between a host country employer and a foreign migrant, while the latter entails a contract for the temporary movement of service providers between a host country employer and a foreign firm. Mode IV would thus be expected to result in a substantially smaller degree of overstaying than the former.

A foreign firm that exports services to a host country under Mode IV can build a reputation for low defection rates in ways that are not feasible in guest-worker programs. There are a number of mechanisms that can help foreign firms achieve this objective, three of which are described here.

First, host countries can hold foreign firms accountable for the behavior of their employees, penalizing them if any of their workers overstays (or if it is more frequent than a specified number of times). Penalties might include large fines or revoking the permit to provide services in the host country. This would provide a strong incentive for foreign firms to screen their workers and monitor their behavior. ${ }^{24}$

Second, employees of a foreign firm that is being penalized would bear part of the cost because the firm might have to lay off some of them. Hence, employees would also have an incentive to monitor each other’s behavior, making it harder to defect.

Third, based on an experiment that takes selection effects into account through random assignment to groups, Goette and Meier (2006) find that the social aspect of

\footnotetext{
${ }^{24}$ If these firms could learn something about the psychic migration cost of prospective employees, they would hire those with high rather than low psychic costs, thereby reducing the overstaying rate. Learning something about prospective employees' psychic migration costs would be more likely if they were related to some observable characteristics. For instance, a married person would probably be less likely to overstay than a single one. Older migrants would also be less likely to overstay because of the smaller number of periods they would be able to benefit from working in the illegal job market compared to younger ones.
} 
organizations can motivate efficient behavior even when ordinary incentives fail. This helps explain practices designed to foster social ties or group identification within an organization. These results would imply that foreign firms hiring source country labor to work in a host country could further reduce the likelihood of defection by selecting workers with shared attributes, including community, ethnicity and religion, because internalization of the cost of their defection on others would be greater.

The difference between Mode IV and guest-worker programs can be expressed in terms of the overstaying probability. It is equal to $v_{\Psi}=W^{I}-\alpha W-W^{S}$ under the guestworker program and is equal to $v_{\Psi}^{\prime}=W^{I}-\alpha W-W^{S}-\kappa$ under Mode IV, where $\kappa>0$ is the cost of an attempt to overstay and which is associated with the monitoring of the migrants' behavior. With $v_{\Psi}^{\prime}=v_{\Psi}-\kappa<v_{\Psi}$, fewer migrants overstay under Mode IV.

The decline in the overstaying rate from $v_{\Psi}$ to $v_{\Psi}^{\prime}$ results in a higher level for $N_{1}^{*}$ and $\alpha^{*}$ (because the reduction in social cost dominates the reduction in government revenue at the optimum), and it has no impact on $N_{2}^{*}$ (because the social cost that period 2 guest-workers impose are unrelated to overstaying and they generate no government revenue).

The optimal value of the objective function $F_{2}$ under Mode IV is greater than that of $F_{1}$ under the guest-worker program, i.e., $F_{2}^{*}>F_{1}^{*}$. The reason is that, at the optimal values of the policy variables under the guest-worker program, a reduction in the share of overstaying guest-workers raises the value of the objective function, and its value also increases as the policy variables reach their new optimal values. 


\section{Permanent Migration}

The social cost or weight $\phi$ natives attach to permanent migration is smaller than that of illegal migration but is greater than that of temporary migration, i.e., $0<\mu<\phi<1$. Given that there is no overstaying or deferred payment in this case, the government's objective function is

$$
F_{3}=g * E B+G B-S C=2 g\left(W^{N}-W\right) N_{P}-\left[3 a+(2 \phi-3 b) N_{P}^{2}\right]
$$

The optimal value for $N_{P}$ is

$$
N_{P}^{*}=\frac{g\left(W^{N}-W\right)}{2 \phi-3 b}
$$

As was the case with $N_{1}^{*}$ and $N_{2}^{*}, N_{P}^{*}$ increases with $g, W^{N}-W$ and $b$, and falls with its own social cost weight $\phi$ (rather than $\mu$ ). Whether $F_{3}^{*}$ is greater than $F_{2}^{*}$ is ambiguous because of two opposing effects: permanent migration does not result in overstaying but its weight $\phi$ in the social cost function is greater than the weight $\mu$ under the guest-worker program.

The numerator of $N_{P}^{*}$ is identical to that of $N_{2}^{*}$. The denominator of the former is $2 \phi-3 b$ while that of the latter is $2(\mu-b)$. Since $\mu<\phi$, which of the denominators is greater is ambiguous, and whether $N_{P}^{*}$ is greater or smaller than $N_{2}^{*}$ is ambiguous as well. 


\section{Temporary and Permanent Migration}

$N_{1}^{*}$ and $N_{2}^{*}$ are positive under temporary migration and $N_{P}^{*}$ is positive under permanent migration. In other words, both programs raise the host country government's objective function. What about a combination of the two? The objective function in this case is

$$
\begin{aligned}
& F_{4}=g * E B+G B-S C=g\left[\left(W^{N}-W\right)\left(N_{1}+N_{2}+2 N_{P}\right)-B N_{1} v_{\Psi}\right]+(\alpha W+B) v_{\Psi} N_{1} \\
& -\left[3 a+\left(v_{\Psi}+\mu-2 b\right) N_{1}^{2}+(\mu-b) N_{2}^{2}+(2 \phi-3 b) N_{P}^{2}\right]
\end{aligned}
$$

It is easy to see that the optimal values of the policy variables are the same as those in the earlier sections, with only one of each of the two policies being implemented. Similarly, the optimum value $F_{4}^{*}=F_{1}^{*}+F_{3}^{*}$ under the guest-worker program and $F_{4}^{*}=$ $F_{2}^{*}+F_{3}^{*}$ under Mode IV. Since $F_{2}^{*}>F_{1}^{*}$, the optimal policy is a combination of Mode IV and permanent migration.

The increase in the number of migrants and terrorist plots and attacks in recent years has resulted in a less hospitable feeling towards immigrants. Given that the parameter $g$ indicates the importance of employers relative to the social cost borne by the rest of the population, the changed feeling towards immigrants can be introduced into the model through a reduction in $g$. This results in a reduction in the size of the guest-worker program (in both periods) and the permanent migration program.

\section{Circular Migration}

Under circular migration, temporary migrants who worked in the host country and returned home at the end of period 1 can return to the host country as guest-workers in 
period 2. If the probability of returning to the host country is equal to 1 , no temporary migrant will overstay because their income would fall.

The social cost is lower in this case since none of the temporary workers overstays, and government revenue is thus lower as well, with the former effect dominating the latter. Thus, circular migration results in an increase in the government's objective function. The optimal size of the guest-worker program is also larger under circular migration than it its absence.

It is unlikely, though, that all the guest-workers that were hired in period 1 would be rehired in period 2, and that no new guest-workers would be hired. Assume that a share $\beta<1$ of the temporary migrants hired in period 1 are rehired in period 2 and that the selection is random. In that case, the share of temporary migrants who overstay is $v_{\Psi}^{\prime \prime}=W^{I}-\alpha W-\left[\beta W^{I}+(1-\beta) W^{S}\right]=v_{\Psi}-\beta\left(W^{I}-W^{S}\right)<v_{\Psi}$, i.e., overstaying is smaller than in the absence of the circular migration program because the expected gains from overstaying are lower.

Overstaying declines with $\beta$ up to a value $\beta=\beta^{\prime \prime}$ where $v_{\Psi}^{\prime \prime}=0$, with $0<\beta^{\prime \prime}=1-\frac{\alpha W}{W^{I}-W^{S}}<1$. Thus, no guest-worker overstays for $\beta \geq \beta$ ", and increases in $\beta$ beyond the level $\beta=\beta^{\prime \prime}$ have no impact on $v_{\Psi}^{\prime \prime}=0$.

\section{Conclusion}

Host countries have implemented permanent and guest-worker immigration programs in recent decades. Moreover, the temporary movement of service providers under Mode IV of the GATS is one of the issues being negotiated at the Doha Round of 
the WTO. Though decisions on what programs to adopt have acquired increased urgency, policy decisions have been complicated because of concern with migrants' massive overstaying in past guest-worker programs in host countries. These countries are no longer willing to pursue migration policies that are seen as having a negative impact. Migration may be severely restricted or even be unsustainable unless host countries perceive it as being beneficial for them. This would hurt prospective migrants and source countries alike. The latter thus have an important stake in ensuring that reformed migration policies benefit both host and source countries, as well as for the migrants themselves, i.e., that they entail a win-win-win outcome.

This paper contributes to the debate on migration policy reform from the host country's viewpoint by examining guest-worker, Mode IV and permanent migration regimes in a model in which the host country maximizes an objective function with respect to i) the size of the migration program, and - in the case of temporary migration ii) the value of a bond employers must buy and iii) the share of migrants' income whose payment is deferred, taking the impact of the policy on source country cooperation on illegal immigration into account. The paper concludes that the optimal policy is a combination of Mode IV and permanent migration. 


\section{$\underline{\text { References }}$}

Amin, Mohammad and Aaditya Mattoo. 2005. "Does Temporary Migration Have to Be Permanent?” Policy Research Working Paper 3582, World Bank.

Black, Richard. 2004. “Making migration more ‘development-friendly’: temporary mobility schemes." Written evidence to the House of Commons International Development Committee (February 20).

Borjas, George. ...

Epstein Gil S., Arye L. Hillman and Avi Weiss. 1999. “Creating illegal immigrants.” Journal of Population Economics 12: 3-21.

Gibney, Matthew J. 2000. "Outside the Protection of the Law. The Situation of Illegal Migrants in Europe.” Refugees Studies Centre. Oxford (July).

Goette, Lorenz and Stephan Meier. 2006. “The Impact of Group Membership on Cooperation and Norm Enforcement: Evidence using Random Assignment to Real Social Groups.” IZA Discussion Paper No. 2020 and Federal Reserve Bank of Boston Working Paper No. 06-7.

Grossman, Gene and Elhanan Helpman. ... "Protection for Sale.” American Economic Review

Hoekman, Bernard, Aaditya Mattoo and Philip English (eds.). 2002. Development, Trade and the WTO. A Handbook. The World Bank. Washington, D.C.

Holzmann, Robert and Rainer Muenz. 2004. "Challenge and Opportunities of International Migration for the EU, Its Member States, Neighboring Countries and Regions: A Policy Note.” $2^{\text {nd }}$ Stockholm Workshop on Global Mobility Regimes, June 11-12. Institute for Future Studies: Stockholm.

IOM (International Organization for Migration). 2004. Memo to the House of Commons International Development Committee.

Martin, Philip L. 2003. "Managing Labor Migration: Temporary Worker Programs for the $21^{\text {st }}$ Century.” ILO International Institute for Labour Studies, Geneva.

Mattoo, Aaditya and Antonia Carzaniga (eds.). 2003. Moving People to Deliver Services. Oxford University Press (for the World Bank).

Pritchett, Lant. 2004. "Labor Mobility and the Development Policy Agenda in the $21^{\text {st }}$ Century.” Mimeo. Harvard University (June). 
Rivera-Batiz, Francisco L. 1999. "Undocumented workers in the labor market: An analysis of earnings of legal and illegal Mexican immigrants to the United States." Journal of Population Economics 12: 91-116.

Ruhs, Martin and Ha-Joon Chang. 2004. "The Ethics of Labor Immigration Policy.” International Organization 58 (winter): 69-102.

Schiff, Maurice. 2002. "Love Thy Neighbor: Social Capital, Trade and Optimal Migration Policy." European Journal of Political Economy (March).

Walmsley, Terrie L. and L. Alan Winters. 2002. "An Analysis of the Removal of Restrictions on the Temporary Movements of Natural Persons.” CEPR Discussion Paper No. 3719.

Winters, L. Alan, Terrie L. Walmsley, Zhen Kun Wang and Roman Grynberg. 2002. "Negotiating the Liberalization of the Temporary Movement of Natural Persons." University of Sussex Discussion Paper 87 (October).

2003. "Liberalising the Temporary Movement of Natural Persons: An Agenda for the Development Round.” World Economy: 1137-61.

06/17/2007 4:47:00 PM

MSchiff

C:Permanent, Guestworker, or Mode IV - 200.doc

06/17/2007 4:47:00 PM 